Boise State University

ScholarWorks

$12-1-2010$

\title{
Comparisons of Carbon Pools and Economic Profitability for Managed Ponderosa Pine Stands in Wyoming, USA
}

\author{
A. Chatterjee \\ University of Wyoming \\ Sian Mooney \\ Boise State University \\ G. F. Vance \\ University of Wyoming
}




\title{
Comparisons of Carbon Pools and Economic Profitability for Managed Ponderosa Pine Stands in Wyoming, USA
}

\author{
A. Chatterjee $\bullet$ S. Mooney $\bullet$ G.F. Vance
}

Received: 2010-03-18; Accepted: 2010-06-08

(C) Northeast Forestry University and Springer-Verlag Berlin Heidelberg 2010

\begin{abstract}
A forest carbon (C) sequestration project was conducted to evaluate the economic incentives that would be required by landowners to engage in $\mathrm{C}$ trading under different management regimes. Costs associated with joint management for $\mathrm{C}$ sequestration and timber would be valuable for establishing sound forest $\mathrm{C}$ trading systems. In this study, we calculated the $\mathrm{C}$ yield and amortized value of three Wyoming, ponderosa pine stands. The management practices examined were, unmanaged, even-aged (regeneration after clear-cut) and uneven-aged (selectively harvested). Costs and revenues associated with three stands were converted into 2006 real dollars using the all commodity producer price index to facilitate a comparison among the net revenues of three stands. Net revenues were annualized using a conservative annual interest rate of $4.5 \%$. Our even-aged stand had the highest annual average $\mathrm{C}$ yield of $2.48 \mathrm{Mg} \cdot \mathrm{ha}^{-1} \cdot \mathrm{a}^{-1}$, whereas, the unevenaged stand had the lowest $\mathrm{C}$ accumulation $\left(1.98 \mathrm{Mg} \cdot \mathrm{ha}^{-1} \cdot \mathrm{a}^{-1}\right)$. Alternatively, the even-aged stand had the highest amortized net return of $\$ 276 \cdot \mathrm{ha}^{-1} \cdot \mathrm{a}^{-1}$ and the unmanaged stand had the lowest net return of $\$ 64 \mathrm{ha}^{-1} \mathrm{a}^{-1}$. On the
\end{abstract}

The online version is available at http://www.springerlink.com

A. Chatterjee ( $)$

Department of Renewable Resources, University of Wyoming, Laramie, WY, 82071, USA. phone: 1-541-278-4390; Fax: 1-541-278-4372; email: forestcarbon@gmail.com;

S. Mooney

Department of Economics, Boise State University, Idaho, 83725, USA

G. F. Vance,

Department of Renewable Resources, University of Wyoming, Laramie, WY, 82071, USA

Responsible editor: Chai Ruihai plots examined, an annual payment of $\$ 22$ for each additional $\mathrm{Mg}$ of $\mathrm{C}$ sequestered would encourage a change from uneven aged management to an unmanaged stand that sequesters additional $\mathrm{C}$, in the absence of transactions costs.

Keywords: ponderosa pine, Wyoming, timber harvest, amortized net revenue, carbon sequestration

\section{Introduction}

Carbon (C) sequestration is a major ecosystem service that forests can provide to mitigate climate change (Lippke and Perez-Garcia 2008). Forest land owners can receive additional payments to sequester $\mathrm{C}$ by creating $\mathrm{C}$ credits and selling them in a market such as the Chicago Climate Exchange (Chicago Climate Exchange 2009)

${ }^{1}$. Under this scenario, land managers would need to decide which management strategy maximizes the net revenues from the joint production of timber and C credits (Pohjola and Valsta 2007). Relatively few studies compared the economics of $\mathrm{C}$ sequestration via stand management practices other than tree planting (Sedjo et al. 1995). Moreover, due to variation in forest types and management practices, there is insufficient information to guide land managers facing a decision about whether or not to change their management practices to generate $C$ credits (Calderia et al. 2004). This paper provides a framework and empirical example that can be used to guide landowners in making decisions about management changes that sequester additional $\mathrm{C}$ with the intention of providing credits into $\mathrm{C}$ markets.

\footnotetext{
${ }^{1}$ Each market for $\mathrm{C}$ credits currently has different contract specifications and administrative rules. A description of each contract design is outside the scope of this paper.
} 
In the case of forest $\mathrm{C}$ management, at least two broad categories of information must be established for a land owner to assess whether managing a stand for timber and $\mathrm{C}$ will result in higher profits than managing a stand for timber only. First, the rate of $\mathrm{C}$ sequestration under different management practices needs to be assessed and second the relative economic costs of each management practice must be examined. This information, together with the prevailing price for $\mathrm{C}$ credits, will determine whether a land owner could profit from establishing practices that result in $\mathrm{C}$ credit payments. In this paper, we studied the economic profitability and potential of developing $\mathrm{C}$ credits using an empirical example of three ponderosa pine stands - unmanaged, even-aged, and uneven-aged - located near the Black Hills National Forest, Wyoming.

\section{Methods}

In Wyoming, ponderosa pine forests are managed as even-aged (regeneration cutting), uneven-aged (selective timber harvest), or as a hybrid, i.e., two or three aged systems and stands that are intermediately managed by thinning and prescribed burning (Sheppard and Battaglia 2002). For this study, three ponderosa pine stands, unmanaged, even-aged, and uneven-aged, were selected near the Black Hills National Forest $\left(44^{\circ} \mathrm{N}, 104^{\circ} \mathrm{W}\right)$ in northeastern Wyoming. Information regarding stand management activities, timber yields, sale prices, and input costs for these stands were collected from personal interviews with state forest land managers. Assumptions based on published literature were made where specific data were unavailable. Detailed accounts of stand management activities, timber harvesting events, and assumptions for these three stands are stated in Table 1.

Table 1. Stand history and assumptions for economic analyses of ponderosa pine stands.

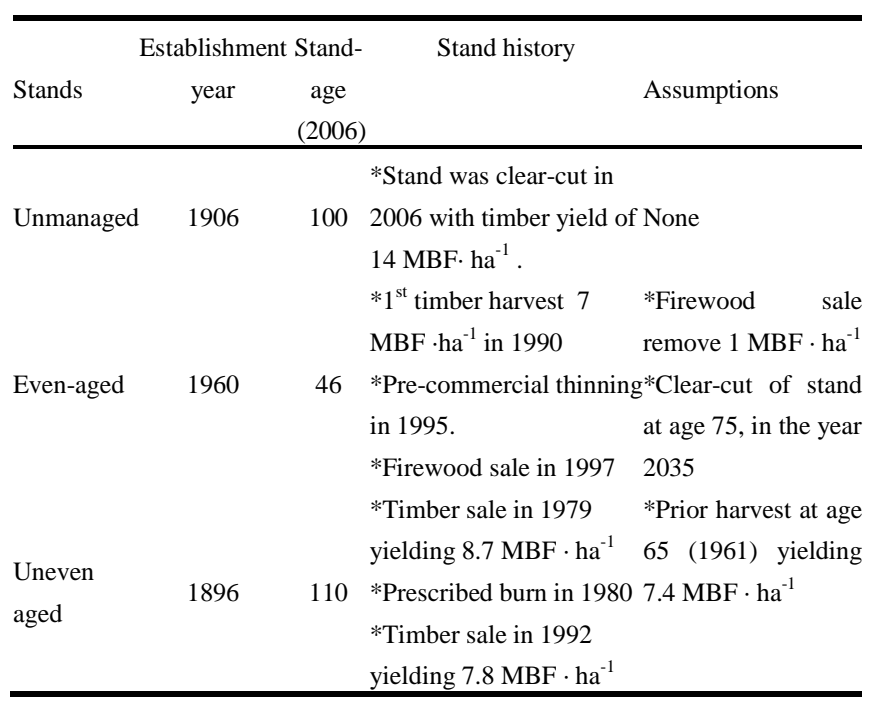

$\mathrm{MBF}=$ thousand board feet

For stand $\mathrm{C}$ inventory calculations, three replicated $50 \times 50 \mathrm{~m}$ plots were established that contained three $50-\mathrm{m}$ transects at $25-\mathrm{m}$ intervals for soil and plant (dead and alive) sample collection. Stand age was determined by the average age of old cohorts. Live tree biomass was measured by the allometric equations developed for these stands (Tinker et al. submitted). For saplings with a dbh less than $7.5 \mathrm{~cm}$, different allometric equations based on basal diameter (bd) were used to calculate biomass (Tinker et al. Submitted). Percent cover of all herbaceous species within each subplot was calculated from twenty-five, $0.25-\mathrm{m}^{2}$ quadrats, and their biomass was determined using allometric equations from Turner et al. (2004). Downed wood biomass was estimated with six 15-m transects placed perpendicular to each 50-m transect at 10-m intervals using the planar intercept method. All aboveground biomass components were converted to biomass $\mathrm{C}$ using a conversion factor of 0.512 (Table 2). Forest floor layers $\left(\mathrm{O}_{\mathrm{i}}\right.$ and $\mathrm{O}_{\mathrm{e}}+\mathrm{O}_{\mathrm{a}}$ layers) were sampled by randomly placing $0.25 \times 0.25 \mathrm{~m}$ quadrats within each subplot for a total of 15 forest floor samples per stand treatment. Weight of air-dried forest floor samples were determined and converted to biomass on a per hectare basis. Soil samples were collected from the starting, mid, and end points of each transect at depths of $0-5,5-15,15-30$ and 30-60 cm, resulting in 36 samples per site for a grand total of 108 samples per stand treatment. Percent total $\mathrm{C}$ concentration of the finely ground and relatively homogeneous forest floor, soil and root samples were determined by dry combustion using an Elementar Vario-Macro CN Analyzer. The SOC pool for a particular soil depth was calculated using organic $\mathrm{C}$ and soil BD and summed to $60 \mathrm{~cm}$ soil depth. Detailed results of $\mathrm{C}$ pool estimates for these stands were presented in Chatterjee et al. (2009).

Stand $\mathrm{C}$ accumulation was calculated as the sum of current total stand $\mathrm{C}$ pool and $\mathrm{C}$ removed during timber harvesting. The $\mathrm{C}$ yield from merchantable wood was calculated using multipliers specific for ponderosa pine that are presented in Table 2 (Birdsey 1996, Sampson 2002). Merchantable timber wood was converted to total plant biomass removed during harvesting. For example, if 4 thousand board feet (MBF) ha ${ }^{-1}$ timber is harvested from a stand, then the amount of timber removed in cubic $\mathrm{ft}$ is $4 \times 0.1650 \times 1000=$ 660 cubic $\mathrm{ft}\left(18.69 \mathrm{~m}^{3}\right)$ of timber, total plant biomass removed during timber harvesting is $660 \times 2.254=1488$ cubic $\mathrm{ft}$, and removal of $\mathrm{C}$ due to harvest is $1488 \times 12.14=18,064 \mathrm{lb}$ or $8.19 \mathrm{Mg}$ of $\mathrm{C}$. The annual average accumulation of $\mathrm{C}\left(\mathrm{Mg} \cdot \mathrm{ha}^{-1} \cdot \mathrm{a}^{-1}\right)$ of a stand was calculated by dividing the total $\mathrm{C}$ yield by the stand age at final harvest. For the even-aged stand, the final harvest was assumed to occur at age 75 , which is a common rotation length followed for even-aged stand management in the Black Hills region (Sheppard and Battaglia 2002). Additional biomass accumulation of the even-aged stand during 29 years (2006-2035) was calculated assuming a mean annual increment of 81.5 cubic $\mathrm{ft}$ per hectare (Boldt et al., 1983). Merchantable timber from the final harvest was 
calculated using conversion factors presented in Table 2. An estimated price of timber in 2035 was obtained from Haynes (2003).

Table 2. Multipliers for conversion of merchantable wood to total plant biomass $\mathrm{C}$ removed during harvesting specific for ponderosa pine (adopted from Birdsey, 1996; Sampson, 2002).

\begin{tabular}{lc}
\hline \multicolumn{1}{c}{ To convert } & $\begin{array}{c}\text { Value/ Conver- } \\
\text { sion factor }\end{array}$ \\
\hline $\begin{array}{l}\text { A. Merchantable wood (MBF) to Cubic } \mathrm{ft}\left(\mathrm{ft}^{3}\right) \\
{[\mathrm{MBF} \text { (Scribner, small) or thousand board feet] }}\end{array}$ & 165 \\
B. Specific Gravity of ponderosa pine wood & 0.38 \\
C. Harvested timber volume $\left(\mathrm{ft}^{3}\right)$ to weight $(\mathrm{lb})$ & 23.71 \\
$(\mathrm{~B} * 62.4)$ & \\
D. Merchantable wood to total plant biomass & 2.254 \\
E. Percent C in plant biomass & 0.512 \\
F. Harvested timber volume $\left(\mathrm{ft}^{-3}\right)$ to Biomass C $(\mathrm{lb})$ & 27.4 \\
$(\mathrm{C} * \mathrm{D} * \mathrm{E})$ & \\
G. lb to Megagram $\left(10^{6} \mathrm{~g}\right)$ & $4.54 \times 10^{-4}$ \\
\hline
\end{tabular}

$\mathrm{MBF}=$ thousand board feet

All costs and revenues were converted into 2006 real US dollars using the all commodity producer price index to facilitate a comparison between the net revenues generated by the different management practices. The (\$2006) net revenue from each management practice was annualized to account for the fact that each practice occurred over a different time period, using the following formula:

$$
R=\frac{V_{o}}{\left[\frac{1-\frac{1}{(1+i)^{n}}}{i}\right]}
$$

where $R=$ value of annual payment or lifetime amortized value, $V_{0}$ $=$ net revenue of each management practice in 2006 dollars, $n=$ time period of investment, and $i=$ interest rate (assumed to be $4.5 \%$ or 0.045$)^{2}$.

\footnotetext{
${ }^{2}$ The choice of interest rate is an often contested point in financial analysis and reflects the likely return on investment. A conservative interest rate of 0.045 was chosen for this analysis. A sensitivity analysis was conducted to examine the impacts of varying the interest rate by up to 3 percentage points higher. Results showed that this had no effect over the relative ranking of the net revenues over the three plots studied.
}

In order to calculate the minimum payment required to encourage a forest manager to switch to practices that increase $\mathrm{C}$ sequestration, but might be less profitable than the existing practice, we need to compare the profitability (net revenue) and $\mathrm{C}$ sequestration potential of each management practice. ${ }^{3}$ The minimum payment required per additional $\mathrm{Mg}$ of $\mathrm{C}$ sequestered can be calculated as follows. ${ }^{4}$ The opportunity cost per ha of sequestering additional $\mathrm{C}$ equals $\pi_{0}-\pi_{a}$ where $\pi_{0}$ represents net returns from the existing management practice and $\pi_{\mathrm{a}}$ represents net returns from an alternative practice. ${ }^{5}$ A producer would be expected to consider adopting a practice that is less profitable but sequesters additional $\mathrm{C}$ when $\pi_{0}-\pi_{a} \leq p \Delta C$, where $\mathrm{p}$ represents a market price per additional $\mathrm{Mg}$ of $\mathrm{C}$ sequestered by the alternative practice and $\Delta \mathrm{C}$ represents the additional $\mathrm{Mg}$ of $\mathrm{C}$ sequestered by the alternative practice. The potential payment per ha $(p \Delta C)$ compensates the producer for the opportunity cost per ha incurred by changing management practices. Rearranging this expression results in $\frac{\pi_{0}-\pi_{a}}{\Delta C} \leq p$, which shows that the price per Mg C must be large enough to compensate the producer for the opportunity cost of sequestering each $\mathrm{Mg}$ of $\mathrm{C}$ before a producer will change management practices.

\section{Results and Discussion}

The unmanaged stand had the highest live tree $\mathrm{C}\left(90.3 \mathrm{Mg} \cdot \mathrm{ha}^{-1}\right)$, followed by even-aged (38.2 Mg.ha $\left.{ }^{-1}\right)$ and uneven-aged (20.5 $\mathrm{Mg} \cdot \mathrm{ha}^{-1}$ ) stands (Table 3 ). Lifetime $\mathrm{C}$ storage was determined to be the highest in the unmanaged stand $\left(248 \mathrm{Mg} \cdot \mathrm{ha}^{-1}\right)$ and lowest in the even-aged stand (194 Mg.ha' ${ }^{-1}$ ) (Table 3). Conversely, annual C yield from the unmanaged stand $\left(2.48 \mathrm{Mg} \cdot h \mathrm{a}^{-1} \cdot \mathrm{a}^{-1}\right)$ was lower than the even-aged stand $\left(2.59 \mathrm{Mg} \cdot \mathrm{ha}^{-1} \cdot \mathrm{a}^{-1}\right)$; however, both stands were

\footnotetext{
${ }^{3}$ The contract specifications for determining what management changes will result in C-credits depend on the market the credits are sold in. Under the Kyoto market, the concept of additionality is key. Under additionality, credit is only provided for projects that are different from "business as usual" i.e. a land manager may change their management practice in a way they would otherwise not have done in the absence of payments for Ccredits.

${ }^{4}$ The discussion implicitly assumes zero transactions costs. In a real life situation there is often transaction cost associated with any transaction. The simple framework above can be expanded to account for transactions costs. A discussion of the effects of accounting for transactions costs can be found in Mooney et al. $(2007,2004)$.

${ }^{5}$ Consistent with accepted economic practice, we assume that managers have already chosen the practice that maximizes their net revenue i.e. $\pi_{0}>$ $\pi_{\mathrm{a}}$.
} 
This is an author-produced, peer-reviewed version of this article. The final publication is available at www.springerlink.com. Copyright restrictions may apply. DOI: 10.1007/s11676-010-0102-3

greater than the uneven-aged stand $\left(1.98 \mathrm{Mg} \cdot \mathrm{ha}^{-1} \cdot \mathrm{a}^{-1}\right)$. The data suggest that the annualized $\mathrm{C}$ sequestration potential of the three management practices on the Wyoming sites is ordered as follows: Uneven aged $<$ unmanaged $<$ even-aged. The even-aged stand had the highest amortized net revenue $\left(\$ 276 \cdot \mathrm{ha}^{-1} \cdot \mathrm{a}^{-1}\right)$ whereas the un- even-aged stand and unmanaged stand had amortized net revenues of $\$ 75$ and $\$ 64 \cdot \mathrm{ha}^{-1} \cdot \mathrm{a}^{-1}$, respectively (Table 4$)$. Of the three studied stands, the even-aged stand attained both maximum annual $\mathrm{C}$ yield and net revenues (Table 5).

Table 3. Lifetime $\mathrm{C}$ yield $\left(\mathrm{Mg}_{\mathrm{ha}} \mathrm{h}^{-1}\right)$ from tree biomass of three stands under different management practices within ponderosa pine forest

\begin{tabular}{|c|c|c|c|c|c|c|c|c|}
\hline \multicolumn{3}{|c|}{ Unmanaged } & \multicolumn{3}{|c|}{ Even-aged } & \multicolumn{3}{|c|}{ Uneven-aged } \\
\hline Age/year & C-source & $\mathrm{Mg} \cdot \mathrm{ha}^{-1} \mathrm{C}$ & Age/year & C-source & $\mathrm{Mg} \cdot \mathrm{ha}^{-1} \mathrm{C}$ & Age/year & C-source & $\mathrm{Mg} \cdot \mathrm{ha}^{-1} \mathrm{C}$ \\
\hline \multirow[t]{11}{*}{$100(2006)$} & Live tree & 90.3 & $30(1990)$ & Harvest $\left(7 \mathrm{MBF} \cdot \mathrm{ha}^{-1}\right)$ & 14.3 & $65(1961)$ & Harvest (7.4 MBF.ha $\left.{ }^{-1}\right)$ & 15.2 \\
\hline & Saplings & 0.29 & 37 (1997) & Firewood (2.5 MBF.ha $\left.{ }^{-1}\right)$ & 5.12 & $83(1979)$ & Harvest (8.7 MBF.ha $\left.{ }^{-1}\right)$ & 17.8 \\
\hline & Herbs & 0.16 & 75 (2035) & Live tree & 38.2 & $96(1992)$ & Harvest (7.8 MBF.ha $\left.{ }^{-1}\right)$ & 15.9 \\
\hline & Dead tree & 7.86 & & Saplings & 0.25 & $110(2006)$ & Live tree & 20.5 \\
\hline & Coarse wood & 22.8 & & Herbs & 0.63 & & Saplings & 0.58 \\
\hline & Forest floor & 17.2 & & Dead tree & 2.26 & & Herbs & 0.79 \\
\hline & Soil & 85.8 & & Coarse wood & 16.2 & & Dead tree & 0.41 \\
\hline & Roots & 23.3 & & Forest floor & 18.6 & & Coarse wood & 6.82 \\
\hline & & & & Soil & 89.2 & & Forest floor & 21.8 \\
\hline & & & & Roots & 9.57 & & Soil & 104 \\
\hline & & & & & & & Roots & 14.6 \\
\hline \multicolumn{2}{|c|}{ Lifetime $\mathrm{C}$ yield $\left(\mathrm{Mg} \cdot \mathrm{ha}^{-1}\right)$} & 248 & & & 194 & & & 218 \\
\hline \multicolumn{2}{|c|}{ Annual C yield $\left(\mathrm{Mg} \cdot \mathrm{ha}^{-1} \mathrm{a}^{-1}\right)$} & 2.48 & & & 2.59 & & & 1.98 \\
\hline
\end{tabular}

Table 4. Amortized net revenue $\left(\$ \mathrm{ha}^{-1 \cdot} \mathrm{a}^{-1}\right)$ and annual average increases in $\mathrm{C}\left(\mathrm{Mg} \cdot \mathrm{ha}^{-1} \cdot \mathrm{a}^{-1}\right)$ for three ponderosa pine stands in $\mathrm{Wyoming}$

\begin{tabular}{|c|c|c|c|c|c|c|c|c|}
\hline \multicolumn{3}{|c|}{ Unmanaged } & \multicolumn{3}{|c|}{ Even-aged } & \multicolumn{3}{|c|}{ Uneven-aged } \\
\hline \multirow[t]{4}{*}{ Age/year } & \multirow[t]{2}{*}{ Activity } & $\begin{array}{l}\text { Value } \\
\left(\$ \mathrm{ha}^{-1}\right)\end{array}$ & \multirow[t]{2}{*}{ Age/year } & \multirow[t]{2}{*}{ Activity } & $\begin{array}{l}\text { Value } \\
\left(\$ \mathrm{ha}^{-1}\right)\end{array}$ & \multirow[t]{2}{*}{ Age/year } & \multirow[t]{2}{*}{ Activity } & $\begin{array}{l}\text { Value } \\
\left(\$ \mathrm{ha}^{-1}\right)\end{array}$ \\
\hline & & $\$ 2006$ & & & $\$ 2006$ & & & $\$ 2006$ \\
\hline & & & $0(1960)$ & Establishment & & $0(1896)$ & Establishment & \\
\hline & & & $30(1990)$ & $\begin{array}{c}\text { Sale } \\
\left(7 \mathrm{MBF} \cdot \mathrm{ha}^{-1}\right)\end{array}$ & 882 & $66(1962)$ & $\begin{array}{l}\text { Sale } \\
\left(7.4 \mathrm{MBF} \cdot \mathrm{ha}^{-1}\right)\end{array}$ & 769 \\
\hline 0 (1906) & Establishment & & 35 (1995) & Thinning & $(326)$ & 83 (1979) & $\begin{array}{c}\text { Sale } \\
\left(8.7 \mathrm{MBF} \cdot \mathrm{ha}^{-1}\right)\end{array}$ & 271 \\
\hline $100(2006)$ & $\begin{array}{l}\text { Stand harvest } \\
\left(14 \mathrm{MBF} \cdot \mathrm{ha}^{-1}\right)\end{array}$ & 1613 & 37 (1997) & $\begin{array}{c}\text { Sale } \\
\left(2.5 \mathrm{MBF} \cdot \mathrm{ha}^{-1}\right)\end{array}$ & 143 & $84(1980)$ & Prescribed burn & (136) \\
\hline $100(2006)$ & Sell preparation & $(215)$ & 75 (2035) & $\begin{array}{l}\text { Stand harvest } \\
\left(18 \mathrm{MBF} \cdot \mathrm{ha}^{-1}\right)\end{array}$ & 5206 & $96(1992)$ & $\begin{array}{c}\text { Sale } \\
\left(7.8 \mathrm{MBF} \cdot \mathrm{ha}^{-1}\right)\end{array}$ & 748 \\
\hline \multicolumn{2}{|c|}{ Net Revenue ha $^{-1}$} & 1398 & & & 5904 & & & 1652 \\
\hline \multicolumn{2}{|c|}{ Project Lifetime (year) } & 100 & & & 75 & & & 110 \\
\hline \multicolumn{2}{|c|}{ Amortized Value $\left(\$ \cdot \mathrm{ha}^{-1} \cdot \mathrm{a}^{-1}\right)$} & 64 & & & 276 & & & 75 \\
\hline
\end{tabular}

Table 5. Changes in amortized net revenue $\left(\$ \cdot h \mathrm{a}^{-1} \cdot \mathrm{a}^{-1}\right)$ and annual average $\mathrm{C}$ yield $\left(\mathrm{Mg} \cdot \mathrm{ha} \mathrm{a}^{-1} \cdot \mathrm{a}^{-1}\right)$ between practices that increase $\mathrm{C}$ sequestration

\begin{tabular}{|c|c|c|c|c|c|c|c|}
\hline & & \multicolumn{6}{|c|}{ Original management practice } \\
\hline & & \multicolumn{3}{|c|}{ Unmanaged } & \multicolumn{3}{|c|}{ Uneven-aged } \\
\hline & & $( \pm)$ Profit & $( \pm) \mathrm{C}$ & $\begin{array}{l}\text { Annual Payment required } \mathrm{Mg} \\
\qquad \mathrm{C}^{-1}\end{array}$ & $( \pm)$ Profit & $( \pm) \mathrm{C}$ & $\begin{array}{l}\text { Annual Payment } \\
\text { required } \mathrm{Mg} \mathrm{C}^{-1}\end{array}$ \\
\hline Alternative Manage- & Unmanaged & 0 & 0 & & $-\$ 11$ & +0.50 & $-\$ 22$ \\
\hline ment & Even-aged & $+\$ 212$ & +0.11 & $\$ 1927$ & $\$ 201$ & +0.61 & $\$ 330$ \\
\hline
\end{tabular}


A payment would be required to encourage a producer to switch from uneven aged management to an unmanaged stand on the plots we considered. A shift from uneven aged management to an unmanaged stand will increase annual average $\mathrm{C}$ sequestration by 0.5 $\mathrm{Mg}$ per year but reduce annualized net revenues by $\$ 11 \cdot \mathrm{ha}^{-1} \cdot \mathrm{a}^{-1}$. In the presence of zero transactions costs the manager would have to receive a payment of at least $\$ 22 \cdot \mathrm{Mg}^{-1} \cdot \mathrm{a}^{-1} \mathrm{C}$ to compensate them for the opportunity cost of switching practices.

The choice of which forest management practice to select depends solely on the land owner's objective. If their goal is economic profitability, even-aged stand is the most profitable option on the plots that we studied in the absence of a $\mathrm{C}$ credit market. ${ }^{6} \mathrm{Man}-$ agement practices that imitate regular natural forest disturbance are likely to achieve the best combination of high economic profitability and C storage (Thornley and Cannell 2000). Results presented here are based on a plot level study and ignored the spatial heterogeneity present at large spatial scales.

\section{References}

Antle J, Capalbo S, Mooney S, Elliott E, Paustian K. 2003. Spatial heterogeneity, contract design, and the efficiency of carbon sequestration policies for agriculture. Journal of Environmental Economics and Management. 46: 231-250.

Birdsey RA. 1996. Carbon storage in United States forests. In: R. N. Sampson, and D. Hair (eds.), Forests and Global Change, Vol. II: Opportunities for Improving Forest Management, American Forests, Washington, DC. pp. 23-39

Boldt CE, Alexander RR, Larson MJ. 1983. Interior ponderosa pine in the Black Hills. In: R.M. Burns, (ed.) Silvicultural Systems for the Major Forest Types of the United States. Agricultural Handbook 445. Washington, D.C., USA, pp $80-83$.

Calderia K, Morgan MG, Baldocchi D, Brewer PG, Chen C-TA, Nabuurs G-J, Nakicenovic N, Robertson GP. 2004. A portfolio of carbon management options. In: C.B. Field, M.R. Raupach (eds.), The global carbon cycle: integrating humans, climate, and the natural world, Island Press, Washington, DC. pp. $103-129$

Chatterjee A. Vance GF, Tinker DB. 2009. Carbon pools of Ponderosa and Lodgepole pine forests. Canadian Journal of Forest Research, 39:1893-1900.

Chicago Climate Exchange. 2009. Forestry carbon emission offsets. Available online at http://www.chicagoclimatex.com/content.jsf?id=242; last accessed March 17, 2010.

Haynes RW. 2003. An Analysis of the Timber Situation in the United States: 1952 to 2050. USDA For. Serv. Gen. Tech. Rep. PNW-GTR-560. Portland, OR. 254 pp.

Huang C, Kronard GD. 2001. The cost of sequestering carbon on private lands. Forest Policy and Economics, 2: 133-142.

Lippke B, Perez-Garcia J. 2008. Will either cap and trade on carbon emissions tax be effective in monetizing carbon as an ecosystem service. Forest Ecology and Management, 256: 2160-2165.

\footnotetext{
${ }^{6}$ The impact of spatial heterogeneity on $\mathrm{C}$ sequestration and economic profitability is explored in Antle et al (2003)
}

Mooney S, Antle J, Capalbo S, Paustian K. 2004. Design and costs of a measurement protocolfor trades in soil carbon credits. Canadian Journal of Agricultural Economics, 52:257-287.

Mooney S, Gerow K, Antle J, Capalbo S, Paustian K. 2007. Reducing standard errors by incorporating spatial autocorrelation into a measurement scheme for soil carbon credits. Climatic Change, 80: 55-72.

Pohjola J, Valsta L. 2007. Carbon credits and management of Scots pine and Norway spruce stands in Finland. Forest Policy and Economics, 9: 789-798.

Sampson RN., 2002. Monitoring and measuring wood carbon. Presented at the Colorado SWCS Conference on Carbon as a Potential Commodity, Denver, CO. Available at http://www.sampsongroup.com/Papers/carbon.htm; last accessed Feb. 6, 2007.

Sedjo RA, Wisniewski J, Sample AV, Kinsman JD. 1995. The economics of managing carbon via forestry: assessment of existing studies. Environmental and Resource Economics, 6: 139-165.

Sheppard WD, Battaglia MA.. 2002. Ecology, silviculture, and management of Black Hills ponderosa pine. USDA For. Serv. Gen. Tech. Rep. RMRS-GTR97. $112 \mathrm{pp}$.

Thornley JHM, Cannell MGR. 2000. Managing forests for wood yield and carbon storage: a theoretical study. Tree Physiology. 20: 477-484.

Tinker DB, Stakes GK, Arcano RM. 2009. Allometric equation development, productivity, and biomass partitioning in managed and unmanaged ponderosa pine stands, Black Hills, Wyoming. Western J. Appl. For. (Submitted)

Turner MG, Tinker DB, Romme WH, Kashian DM, Litton CM. 2004. Landscape pattern of sapling density, leaf area, and aboveground net primary production in postfire lodgepole pine forests, Yellowstone National Park (USA). Ecosystems, 7: 751-775. 